\title{
The Dominant Factor Affecting Customer Buying Decisions at Online Retail Stores in Jakarta
}

\author{
Rudy Santosa Sudirga \\ Universitas Bunda Mulia, DKI Jakarta 14430, Indonesia
}

\begin{abstract}
A B S T R A C T
Research on the dominant factors affecting customer buying decisions at online retail stores in Jakarta is based on increasing competition in online retail store businesses such as Tokopedia, Bukalapak, Lazada Indonesia, Kaskus, and others. This increase will have a good impact on improving the economy and also increasing the workforce in Indonesia. The author wishes to find out which of the most dominant factors greatly influences customer buying decisions in shopping at retail stores online in Jakarta. The results of respondents who answered the questions were dominated by respondents with a bachelor degree education background, 110 people (55\%), with ages ranging between 31 - 40 years, 114 people (57\%), and have an income of 11 - 30 million rupiah per month, 121 people $(60.50 \%)$, and according to the frequent online shopping between 2-3 times per month, 101 people $(50.50 \%)$. Based on the results of data processing, there are 6 most dominant factors that influence customer buying decisions in shopping at online retail stores in Jakarta. These factors are Variable Attitudes with Estimate value $=1,325$, Time and Cost Efficiency Variable with Estimate value $=1,272$, Variable Values with Estimate value $=1,243$, Family Variable with Estimate value $=1,215$, Beliefs Variable with Estimate value $=1,197$, Variety of Choices Variable with Estimate value = 1,091.
\end{abstract}

ART ICLE INFO

Article History:

Received : 29-06-2020

Revised : 08-01-2021

Accepted : 09-01-2021

Published : 15-02-2021

Keywords:

Attitudes

Time and Cost Efficiency

Values

Family
*Corresponding Author E-mail:

rudysudirga@yahoo.com

Copyright (C) 2021 Authors. This is an open access article distributed under the Creative Commons Attribution License (CC-BY-SA 4.0) which permits use, distribution and reproduction in any medium, provided the original work is properly cited \& ShareAlike terms followed.

\section{INTRODUCTION}

The background of this research is increasing competition in the online retail store business such as Tokopedia, Bukalapak, Lazada Indonesia, Kaskus, OLX Indonesia, Blanja.com, Bhinneka, Blibli, Elevenia, Zalora Indonesia, Shopee, and others. This increase will have a good impact on improving the economy and also increasing the workforce in Indonesia. The author wishes to find out which of the most dominant factors greatly influences customer buying decisions in shopping at online retail stores. So that the online retail store business can continue to improve and develop 
well, the author wishes to conduct research with the title: the dominant factors that influence customer buying decisions at online retail stores in Jakarta. With the rapid development of shopping through retail online stores in Jakarta, the author wishes to analyze and evaluate what are the dominant factor that most influences customer buying decisions at retail online stores in Jakarta. This study aims to determine what are the most dominant factors that influence customer buying decisions in the process of purchasing products at retail online stores in Jakarta. With the rapid growth of online retail store business, especially in Jakarta today, this research is very useful to find out whether these factors have a significant influence on improving the business and performance of online retail stores in Jakarta. In the long run it is very useful to know whether these factors can be used / applied to improve business and performance at online retail stores in Indonesia.

\section{LITERATURE REVIEW}

According to Hammond (2018), in recent years, online purchasing or online shopping has entered a global scale with the growing internet in popularity. According to Edwar, M. et al (2018), purchases through online shopping will have many advantages if it is compared to physical purchases at the store. Online shopping will save the time and you do not need to wait in long queues at the cashier. Online shopping marketplace can be available anytime and anywhere. According to Berman et al. (2017), there are stages of purchase decisions: problem recognition, looking for alternatives, purchasing, and post purchase behavior. Consumer buying decisions are also influenced by several important factors as follows:

1. Saving Money

According to Jobber, Lancaster (2018), online shopping saves money since it reduces costs of product and search. Therefore, consumers will be able to buy products at lower prices. When consumers realize that they get products with the same quality and at lower prices, they may be willing to buy.

2. Variety of Choices
According to Vedamani (2018), Mollahasani et al. 2011 as cited in Bastam H et al. (2017), online stores provide more diverse products for selection because they are not under pressure in terms of space and place like other physical stores.

3. Convenience

According to Hammond (2018), some people might have bad experiences with the shop, therefore some consumers prefer to make their own decisions by online shopping. Some consumers use online channels just to escape from face to face interaction because they are pressure or uncomfortable when dealing with the shop or salespeople.

4. Ease of Use

According to Gilbert D. (2006), the case of ease of use refers to the situation where the whole process of making an online purchase is easier and does not require specialized struggles.

5. Time and Cost Efficiency

According to Berman et al. (2017), consumers did not have to spend more times and money to look for products in some local stores. Since online stores offer consumers with a variety of products and services, it gives consumers more chances to compare prices from different online stores.

According to Levy et al. (2018) and Berman et al. (2017), the factors influencing the buying decision process are as follows:

1. Beliefs

About performance of retailers and products.

So it's about trusting retailers and their products.

2. Values

Whether the purchase of the product is a necessity and the product can be searched at the online retail store.

3. Attitudes

Before making a product purchase, the customer usually evaluates the product and the retailer that sells the product.

4. Family

Families also make purchase decisions and how various family members influence these 
decisions. Children play an important role in family buying decisions.

5. Reference Group

A reference group is one or more people who will provide of comparison for beliefs, feelings, and behaviors. These reference groups affect buying decisions by (1) offering information, (2) providing rewards for specific purchasing behaviors, and (3) enhancing a consumer's self-image.

6. Culture

Cultures is the meaning, beliefs, morals, and values shared by most members of a society. For example, an important value in most western cultures is individualism; people should only look out for themselves. However, eastern cultures value collectives, which emphasizes that the considerations of others should guide behavior. Research has found that collectives are more price sensitive than individualistic consumers about private goods (products and services consumed privately) but less price sensitive about public goods.

\section{RESEARCH METHOD}

According to Wijaya, $\mathrm{T}$ (2013), the basic assumption that must be fulfilled in SEM (Structural Equation Modeling) analysis is the number of samples that meet the analytical rules. According to Sekaran, Uma (2003) SEM analysis requires a sample of at least 5 times the number of indicator variables used. The Maximum Likelihood Estimation technique requires samples ranging from 100-200 samples. According to Hair, Black, Babin, Anderson (2010), regarding the sample size question, the researcher generally would not factor in analyzing a sample of fewer than 50 observations, and preferably the sample size should be 100 or larger. As a general rule, the minimum is to have at least five times as many observations as the number of variables to be analyzed, and the more acceptable sample size would have a 10: 1 ratio. In collecting the necessary research data, the author collected primary data by distributing questionnaires to retail customers in Jakarta, who shop at retail stores such as Carrefour, Diamond Supermarket, Farmers Market, Giant, Hypermart and Lotte, because generally people who shop in retail stores most have ever done shopping at retail stores online. In addition, questionnaires were also distributed to online retail store customers in Jakarta and visitors to shopping malls in Jakarta, and the author took 200 research samples.

The sampling technique used by the author is non-probability sampling. According to Sumarni and Wahyuni (2006), non-probability sampling is sampling with the probability of the selected population element unknown. This technique does not provide equal opportunity for each element or member of the population to be

Table 1. Research Roadmap

\begin{tabular}{|c|c|c|c|c|c|}
\hline & $\mathbf{Y}$ & $\mathbf{Y}$ & $\mathbf{Y}$ & $\mathbf{Y}$ & $\mathbf{Y}$ \\
\hline Research Title & Starts & Apr 2020 & May 2020 & Jun 2020 & Jul 2020 \\
\hline $\begin{array}{l}\text { A Study of Factors Affecting Consumer } \\
\text { Buying Behaviour in Online Shopping } \\
\text { (Case Study: Digikala Online Service), } \\
\text { Hadi Bastam, Vahideh Tabasi Lotfabadi, } \\
\text { Vahidreza Kouchakzadeh, } \\
\text { Mozhgan Faraji, } 2017\end{array}$ & $\begin{array}{l}\text { Started } \\
\text { research and } \\
\text { finished in } \\
2017\end{array}$ & & & & \\
\hline $\begin{array}{l}\text { The Factors That Affecting the Product } \\
\text { Purchasing Decision Through Online } \\
\text { Shopping By Students of Surabaya State } \\
\text { University, Muhammad Edwar, Rizki Ayu } \\
\text { Agustin Diansari, Nur Fahmi Winawati, } \\
2018\end{array}$ & $\begin{array}{l}\text { Started } \\
\text { research and } \\
\text { finished in } \\
2018\end{array}$ & & & & \\
\hline $\begin{array}{l}\text { The Dominant Factor Affecting Customer } \\
\text { Buying Decisions at Online Retail } \\
\text { Stores in Jakarta. }\end{array}$ & $\begin{array}{l}\text { Started } \\
\text { research and } \\
\text { finished in } \\
2020\end{array}$ & $\begin{array}{l}\text { Plan research } \\
\text { and prepare } \\
\text { questionnaires }\end{array}$ & Collect data & Collect data & $\begin{array}{l}\text { End research } \\
\text { and submit } \\
\text { report }\end{array}$ \\
\hline
\end{tabular}


selected as a sample. The research instrument was a questionnaire and used a 5-level Likert scale, and the results were used for factor analysis data processing.

Table 2. Profile of Respondents by Education

\begin{tabular}{ccc}
\hline Education & $\begin{array}{c}\text { Number of } \\
\text { Respondents }\end{array}$ & $\begin{array}{c}\text { Percentage } \\
\text { (\%) }\end{array}$ \\
\hline Primary School & - & - \\
\hline Junior High School & 2 & 1.00 \\
\hline Senior High School & 76 & 38.00 \\
\hline Bachelor Degree & 110 & 55.00 \\
\hline Master Degree & 12 & 6.00 \\
\hline Doctoral Degree & - & - \\
\hline Other & - & $\mathbf{1 0 0}$ \\
\hline Total & $\mathbf{2 0 0}$ &
\end{tabular}

Table 3. Profile of Respondents by Age

\begin{tabular}{ccc}
\hline Age (Year) & $\begin{array}{c}\text { Number of } \\
\text { Respondents }\end{array}$ & $\begin{array}{c}\text { Percentage } \\
\text { (\%) }\end{array}$ \\
\hline $10-20$ & - & - \\
\hline $21-30$ & 10 & 5.00 \\
\hline $31-40$ & 114 & 57.00 \\
\hline $41-50$ & 68 & 34.00 \\
\hline $51-60$ & 8 & 4.00 \\
\hline $61-70$ & - & - \\
\hline $71-80$ & - & $\mathbf{1 0 0}$ \\
\hline Total & $\mathbf{2 0 0}$ &
\end{tabular}

Table 4. Profile of Respondents by Income

\begin{tabular}{ccc}
\hline Income/Month & $\begin{array}{c}\text { Number of } \\
\text { Respondents }\end{array}$ & $\begin{array}{c}\text { Percentage } \\
\mathbf{( \% )}\end{array}$ \\
\hline$<10$ million rupiah & 5 & 2.50 \\
\hline $11-30$ million rupiah & 121 & 60.50 \\
\hline $31-50$ million rupiah & 63 & 31.50 \\
\hline $51-70$ million rupiah & 7 & 3.50 \\
\hline $71-90$ million rupiah & 3 & 1.50 \\
\hline$>90$ million rupiah & 1 & 0.50 \\
\hline Total & $\mathbf{2 0 0}$ & $\mathbf{1 0 0}$ \\
\hline
\end{tabular}

Table 5. Profile of Respondents by Frequency of Online Shopping

\begin{tabular}{ccc}
\hline $\begin{array}{c}\text { Online } \\
\text { Shopping/Month }\end{array}$ & $\begin{array}{c}\text { Number of } \\
\text { Respondents }\end{array}$ & $\begin{array}{c}\text { Percentage } \\
\text { (\%) }\end{array}$ \\
\hline 1 & 29 & 14.50 \\
\hline $2-3$ & 101 & 50.50 \\
\hline $4-5$ & 41 & 20.50 \\
\hline $6-10$ & 27 & 13.50 \\
\hline$>10$ & 2 & 1.00 \\
\hline Total & $\mathbf{2 0 0}$ & $\mathbf{1 0 0}$ \\
\hline
\end{tabular}

The data analysis technique that will be used by the author is factor analysis. According to Hair, Black, Babin, Anderson (2010), in general, factor analysis is used to identify a number of factors or variables that have the same character. Thus, researchers can discard and include some variables that have correlations, can use several variables with little correlation coefficient or just use variables that have the same character so that in the analysis only include variables that have sufficient and significant correlations.

For this causal research, the author processes research data with Structural Equation Modeling with IBM SPSS Amos version 23. According to Wijaya, $T$ (2013), the main purpose of SEM analysis is to test the suitability of a model that is the suitability of theoretical models with empirical data.

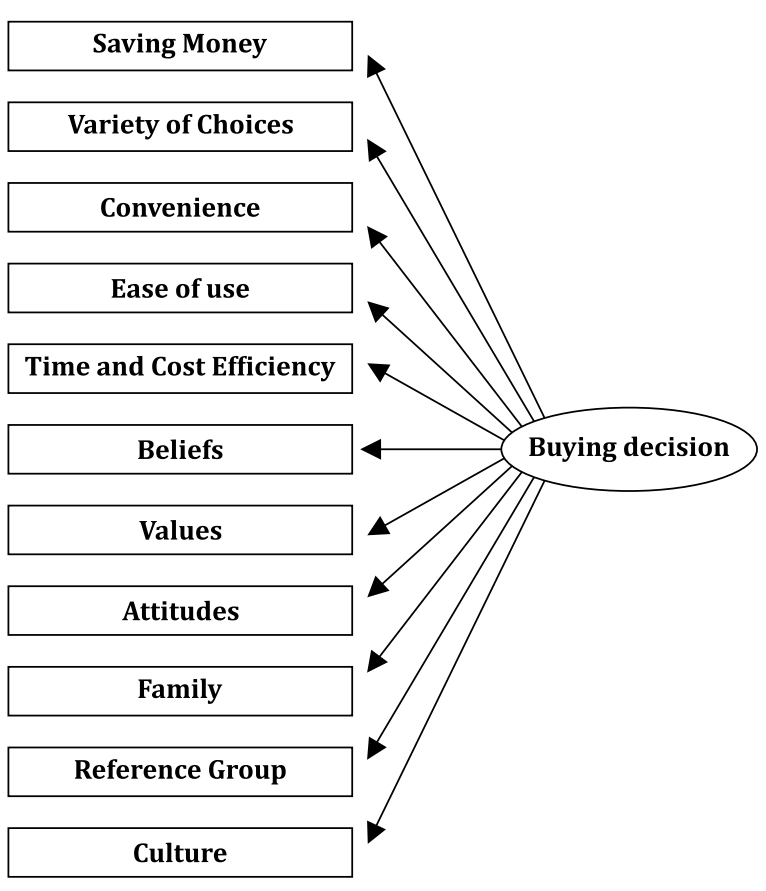

Figure 1. Factor Analysis

Source: Wijaya, T (2013), factor analysis diagram

\section{RESULT AND DISCUSSION}

Based on the results of data processing with Structural Equation Modeling Amos that can be seen in figure 2, it found that the results of the factor analysis met the criteria for the study and all items in the study were valid for each research variables. 


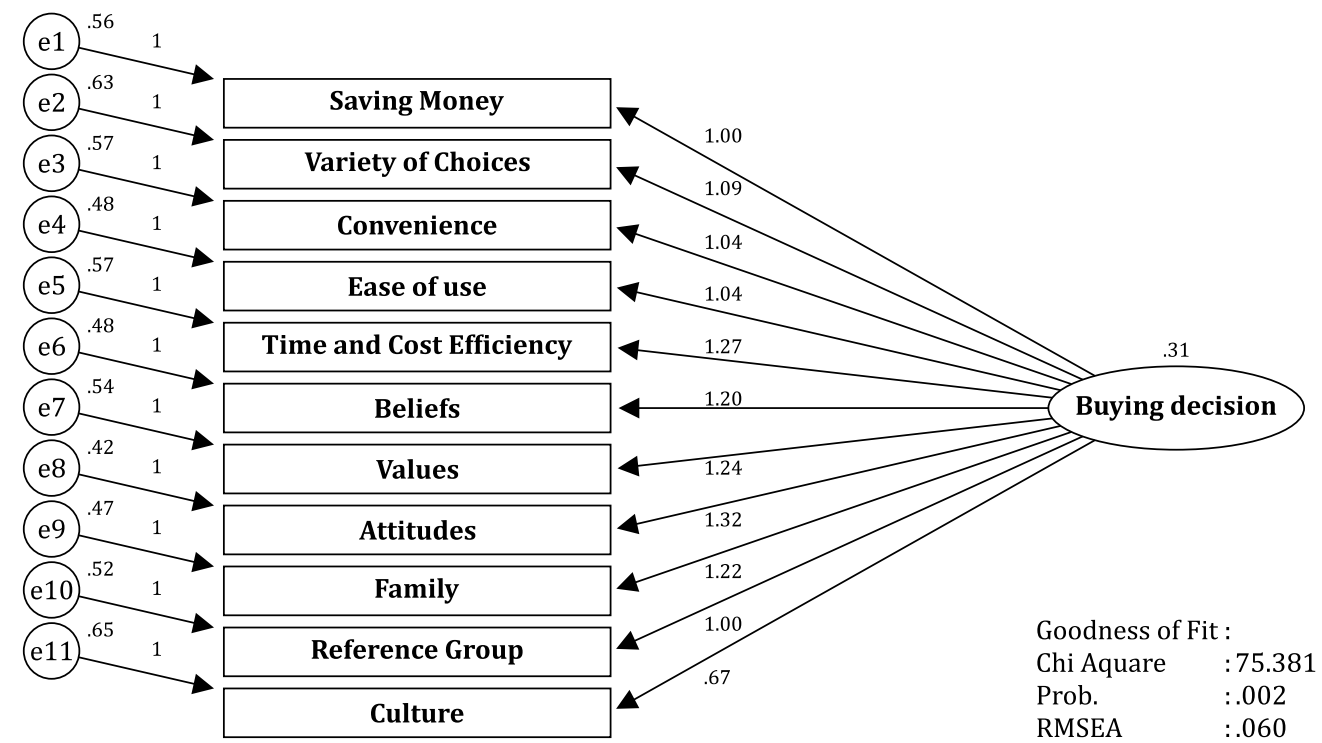

Figure 2. Output Data Analysis

Table 7. Regression Weights

\begin{tabular}{clllllll}
\hline & & & Estimate & S.E. & C.R. & P & Label \\
\hline q1 & $<--$ & BuyingDecision & 1.000 & & & & \\
\hline q2 & $<---$ & BuyingDecision & 1.091 & 0.154 & 7.091 & $* * *$ & par_1 \\
\hline q3 & $<---$ & BuyingDecision & 1.044 & 0.147 & 7.111 & $* * *$ & par_2 \\
\hline q4 & $<---$ & BuyingDecision & 1.044 & 0.144 & 7.241 & $* * *$ & par_3 \\
\hline q5 & $<---$ & BuyingDecision & 1.272 & 0.165 & 7.703 & $* * *$ & par_4 \\
\hline q6 & $<---$ & BuyingDecision & 1.197 & 0.156 & 7.670 & $* * *$ & par_5 \\
\hline q7 & $<---$ & BuyingDecision & 1.243 & 0.161 & 7.722 & $* * *$ & par_6 \\
\hline q8 & $<---$ & BuyingDecision & 1.325 & 0.165 & 8.007 & $* * *$ & par_7 \\
\hline q9 & $<---$ & BuyingDecision & 1.215 & 0.156 & 7.793 & $* * *$ & par_8 \\
\hline q10 & $<---$ & BuyingDecision & 1.004 & 0.143 & 7.034 & $* * *$ & par_9 \\
\hline q11 & $<---$ & BuyingDecision & 0.667 & 0.13 & 5.118 & $* * *$ & par_10 \\
\hline
\end{tabular}

Table 6. Goodness of Fit Criteria

\begin{tabular}{ccc}
\hline Index Criteria & Reference Value & Output Results \\
\hline Chi Square ( 02 ) & As small as possible & 75.381 \\
\hline CMIN/df & $\leq 2.00$ & 1.713 \\
\hline RMSEA & $\leq 0.08$ & 0.060 \\
\hline GFI & Close to 1 & 0.934 \\
\hline AGFI & Close to 1 & 0.901 \\
\hline TLI & Close to 1 & 0.949 \\
\hline CFI & Close to 1 & 0.959 \\
\hline
\end{tabular}

Source: Wijaya, T (2013), Goodness of Fit Criteria

According to Wijaya, $\mathrm{T}$ (2013), the value of regression weights in Table 7 shows that the value of nadir (critical ratio) is greater than twice the standard error, which means all items in the study are valid for each convergent research variable. Hair, Black, Babin, Anderson (2010), in general, factor analysis is used to test the adequacy of the relationship between variables where the identity matrix contains a diagonal matrix with a value of Eigenvalue $>1$. (Eigenvalue represents the total variance explained by each factor, so that Eigenvalue is a number or a value that shows the total variance of each factor that can be explained by new factors that are formed). From Table 7 it is found that the most dominant factor formed is the factor with Estimate value $>1$ $=$ Eigenvalue value $>1$, and the most dominant factor is the factor with the largest Estimate value or the factor with the largest Critical Ratio (C.R.) value. 
From Figure 2 and Table 7 it can be concluded that the factors influence customer buying decisions at retail online stores in Jakarta, from the most dominant to the lowest with an Estimate value $>1=$ Eigenvalue $>1$ are as follows:

- Attitudes variable with Estimate value = 1.325

- Time and Cost Efficiency variable with Estimate value $=1,272$

- Values variable with Estimate value $=1,243$

- $\quad$ Family variable with Estimate value $=1,215$

- $\quad$ Beliefs variable with Estimate value =1,197

- Variety of Choices variable with Estimate value $=1,091$

- Convenience variable with Estimate value = 1,044

- Ease of Use variable with Estimate value = 1,044

- Reference Group variable with Estimate value $=1,004$

- $\quad$ Saving Money variable with Estimate value = 1,000

While Culture variable is not a factor that influences customer buying decisions at online retail stores in Jakarta, because it has an Estimate value $=$ Eigenvalue $=0.667<1$, because the Eigenvalue value must be $>1$.

\section{CONCLUSION}

The results of respondents who answered the questions were dominated by respondents with a bachelor degree education background 110 people (55\%), with ages ranging between $31-40$ years 114 people (57\%), and have an income of 11 - 30 million rupiah per month 121 people (60.50\%), and with the frequent online shopping between 2-3 times per month 101 people $(50.50 \%)$, so it can be categorized that the majority of users of online retail shopping store in Jakarta are middle class with bachelor degree education, at an age range that is still productive between 31 - 40 years, and has an income of 11 - 30 million rupiah per month.

Attitudes variable with Estimate value $=1.325$ is the most dominant factor that greatly influences customer buying decisions in shopping at online retail stores in Jakarta. This is also reinforced by
Babar, A., Rasheed, A., Sajjad, M. (2014) and Bastam, H, Lotfabadi, V., T., Kouchakzadeh, V., Faraji, M. (2017), who explain that attitudes are the most influential factor in consumer buying decisions on online shopping.

Time and Cost Efficiency variable with Estimate value $=1,272$, Values variable with Estimate value $=1,243$, Family variable with Estimate value = 1,215, Beliefs variable with Estimate value $=1,197$, Convenience variable with Estimate value $=1,044$, Ease of Use variable with Estimate value $=1,044$, and the Reference Group variable with Estimate value $=1,004$, are also factors that influence customer buying decisions in shopping at online retail stores in Jakarta. This is also reinforced by Indriani, I., A., D. (2016), and Edwar, M., Diansari, R., A., G., Winawati, N., F. (2018), who explained that Time and Cost Efficiency, Values, Family, Beliefs, Convenience, Ease of Use, and Reference Group variables are very significant factors that influence consumer purchasing decisions on online shopping.

Variety of Choices variable with Estimate value = 1,091, and Saving Money variable with Estimate value $=1,000$, are also factors that influence customer buying decisions in shopping at online retail stores in Jakarta. This is also reinforced by Bastam, H, Lotfabadi, V., T., Kouchakzadeh, V., Faraji, M. (2017), who explain that Variety of Choices are the most influential factor in consumer purchasing decisions on online shopping.

Based on the results of data processing with Structural Equation Modeling with IBM SPSS Amos version 23, there are 6 most dominant factors that influence customer buying decisions in shopping at online retail stores in Jakarta. These factors are Attitudes variable with Estimate value $=1,325$, Time and Cost Efficiency variable with Estimate value $=1.272$, Values variable with Estimate value $=1,243$, Family variable with Estimate value $=1,215$, Beliefs variable with Estimate value $=1,197$, Variety of Choices variable with Estimate value $=1,091$. Based on this data, the suggestions from the author are as follows: 
1. Online retailers should do things that make an evaluation of the product, whether it is suitable, feasible and of good quality at an adequate price, and also online retailers must provide an image of trust to consumers, because customers will conduct an evaluation before making a purchase of the product and also an evaluation of the online retailers who sell these products (Attitudes variable).

2. Online retailers should do and update the appearance and content of the website, because customers will browse the website before making a purchase, and the ease and time to find the product sought on the website is very important for consumers (Time and Cost Efficiency variable).

3. Online retailers should do something interesting for the promotion of products that are important to consumers, because consumers will be interested in buying products of interest if consumers are interested in the appearance of the website (Values variable).

4. Online retailers should do something interesting for the promotion of products that are important for the needs of the consumers' family, because purchasing decisions are influenced by family factors (Family variable).

5. Online retailers should provide an image of trust to consumers, because customers will conduct an evaluation of online retailers who sell these products (Beliefs variable).

6. Online retailers should have a variety of variations, specifically only for all fast moving consumer goods products both in terms of brand, quality, choice, price, size, type, color, and others. Thus customers do not need to move to other online retailers, because customers have found the product according to their needs (Variety of Choices variable).

\section{REFERENCES}

Berman, R., Evans, J.R., Chatterjee, P.M. (2017). Retail Management: A Strategic Approach, International Edition (13 $3^{\text {th }}$ ed.). Pearson Education, Inc., USA.

Gilbert, D. (2006). Retail Marketing Management ( $2^{\text {nd }}$ ed.). Pearson Education, Inc., Upper Saddle River, New Jersey.

Hair, Black, Babin, Anderson. (2010). Multivariate Data Analysis ( $7^{\text {th }}$ ed.). Pearson Education, Inc., Upper Saddle River, New Jersey.

Hammond, R. (2018). Winning Ideas and Strategies From The Most Successful Retailers in The World ( $4^{\text {th }}$ ed.). Pearson Education, Inc., USA.

Jobber, D., Lancaster, G. (2018). Selling and Sales Management (13 ${ }^{\text {th }}$ ed.). Pearson Education, Inc., USA. Levy, M., Weitz, B. A., Grewal, D. (2018). Retailing Management (10 ${ }^{\text {th }}$ ed.). Pearson Education, Inc., USA.

Mollahasani, S., Omran, M, Mohammad, Afshari, J., Ahmad. (2011). Provision of online consumer behavior models in e-commerce and their application in designing online marketing system. Non-profit and non-governmental Shomal University, Amol, Faculty of Industrial Engineering, Master Thesis.

Sekaran, Uma. (2003). Research Methods for Business - A Skill Building Approach (4 ${ }^{\text {th }}$ ed.). John Wiley \& Sons, USA.

Sumarni, M., Wahyuni, S. (2006). Metodologi Penelitian Bisnis ( $1^{\text {st }}$ ed.). Penerbit ANDI, Yogyakarta.

Vedamani, G., G. (2017). Retail Management ( $5^{\text {th }}$ ed.). Pearson Education, Inc., USA.

Wijaya, T. (2013), Analisis Structural Equation Modeling Menggunakan AMOS ( $5^{\text {th }}$ ed.). Penerbit Universitas Atma Jaya, Yogyakarta.

Babar, A., Rasheed, A., Sajjad, M. (2014). Factors Influencing Online Shopping Behavior of Consumers, Journal Basic and Applied Science, Res., 4(4), pp.314-320.

Bastam, H, Lotfabadi, V., T., Kouchakzadeh, V., Faraji, M. (2017). A Study of Factors Affecting Consumer Buying Behaviour in Online Shopping (Case Study: Digikala Online Store), International Journal of Business and Technopreneurship, Vol. 7, No. 3, pp.369-384. 
Edwar, M., Diansari, R., A., G., Winawati, N., F. (2018). The Factors That Affecting the Product Purchasing Decision Through Online Shopping By Students of Surabaya State University, International Journal of Educational Research Review, 3(4), pp.54-64.

Sudirga, R., S. (2019). Factors that determine the performance improvement of small and medium enterprises in Jakarta, Jurnal Entrepreneur dan Entrepreneurship, Vol. 8, No.1, pp.1-16. 